\title{
Indeks Perdagingan Sapi Bali Jantan dan Betina dari Pemeliharaan Tradisional di Sulawesi Tenggara
}

\section{(Observation of male and female Bali Cattle Feshing Index from Traditional Rearing in Southeast Sulawesi)}

\author{
Hafid $\mathrm{H}^{1}$, Patriani $\mathrm{P}^{2}$, $\operatorname{Irman}^{1}$, Aka $\mathrm{R}^{1}$ \\ ${ }^{1}$ Jurusan Peternakan Fakultas Peternakan Universitas Halu Oleo, Kendari 93232 \\ ${ }^{2}$ Jurusan Peternakan Fakultas Pertanian Universitas Sumatera Utara Medan 20155 \\ harapin.hafid@uho.ac.id
}

\begin{abstract}
Carcass and beef productions of local cattle in Indonesia are very diverse according to characteristics of the region and its raising patterns. This study aimed to measure fleshing index of male and female Balinese cattle that were carried out in Kendari City slaughterhouse. This study used 20 male and 20 female of Balinese cows. Cows have moderate body conditions with a range of 2 to 3.5 years. The variables observed in this study are slaughter weight, carcass weight, carcass length and fleshing index. Data was tabulated based on gender classification, were then analyzed using $\mathrm{t}$ - Student test. The results showed that the average fleshing indexs of male and female Bali cattle were 1.13 and 1.09 , respectively $(\mathrm{P}>0.05)$. Cutting weight of male Bali cattle was significantly different from female Bali cattle (230 vs $212 \mathrm{~kg}$, respectively, $\mathrm{P}<0.05$ ). The carcass weight of male Bali cattle was also significantly different from that of female cattle (122.9 vs $114.1 \mathrm{~kg})$. Male carcass length was significantly longer than that of female cattle (108.9 vs $104.7 \mathrm{~cm}, \mathrm{P}<0.05)$. It can be concluded that there was no significant difference between male and female Bali cattle of fleshing index. However, there were significantly higher on body weight, carcass weight and length of carcass of male Bali cattle compared to those of females.
\end{abstract}

Key words: Bali cattle, carcass weight, fleshing index

\begin{abstract}
ABSTRAK
Produktivitas karkas dan daging sapi lokal di Indonesia masih sangat beragam sesuai dengan karakteristik wilayah dan pola pemeliharaannya. Penelitian ini mempelajari indeks perdagingan sapi Bali jantan dan betina di rumah potong hewan Kota Kendari. Metode penelitian yang digunakan adalah pengamatan dengan penimbangan langsung di lapangan. Variabel yang diamati dalam penelitian ini adalah bobot potong, bobot karkas, panjang karkas dan indeks perdagingan. Data yang diperoleh, ditabulasi berdasarkan klasifikasi jenis kelamin selanjutnya dianalisis dengan menggunakan uji $t$ - Student. Hasil penelitian menunjukan bahwa rataan indeks perdagingan sapi Bali jantan sebesar 1,13 dan sapi Bali betina 1,09 adalah $(\mathrm{P}>0,05)$. Bobot potong sapi Bali jantan sebesar 230 sedangkan betina 212 adalah berbeda nyata $(\mathrm{P}<0,05)$. Bobot karkas sapi Bali Jantan sebesar 122,9 sedangkan betina sebesar 114,1. Jadi, karkas sapi jantan lebih tinggi di bandingkan dengan sapi betina menunjukan berbeda nyata $(\mathrm{P}<0,05)$, dan untuk panjang karkas jantan sebesar 108,9 sedangkan sapi betina sebesar 104,7 berbeda nyata $(\mathrm{P}<0,05)$. Dapat disimpulkan bahwa tidak ada perbedaan nyata antara indeks perdagingan sapi Bali jantan 1,13 dengan sapi Bali betina 1,09. Namun bobot badan,bobot karkas dan panjang karkas sapi Bali jantan nyata lebih besar daripada betina.
\end{abstract}

Kata kunci: Sapi Bali, bobot karkas, indeks perdagingan 


\section{PENDAHULUAN}

Ternak sapi merupakan ternak penghasil daging yang memiliki ekonomi yang tinggi dan sangat penting artinya dalam kehidupan manusia bermanfaat untuk memenuhi kebutuhan akan gizi yang seimbang terutama yang kaya akan protein, lemak, vitamin, mineral serta zat-zat lainnya yang dibutuhkan oleh tubuh. Permintaan daging akan meningkat seiring dengan pertambahan jumlah penduduk. Menurut Badan Pusat Statistik (2015) produksi daging sapi dalam negeri mencapai 485.335 ton tahun 2011, 508.905 ton tahun 2012, 504.819 ton tahun 2013, dan 539.965 ton tahun 2014.

Di Indonesia sampai saat ini biasanya untuk mengatasi kekurangan daging sapi selalu ditutupi dengan daging impor. Daging sapi impor yang masuk ke Indonesia sangat merugikan para pengusaha dan peternak sapi di Indonesia. Padahal tanpa harus impor daging sapi dari Mancanegara seperti Australia, Kebutuhan daging sapi di Indonesia sebenarnya masih bisa dipenuhi oleh para peternak sapi di Indonesia. Mengimpor daging ke Indonesia sama saja mematikan harga daging sapi para peternak lokal. Ini akan sangat membahayakan bagi perekonomian negara ini di masa yang akan datang. Karena nanti para pengusaha dan peternak sapi tidak ingin kembali membudidayakan sapi lokal seperti sapi Madura, sapi Bali dan sapi Peranakan Ongole.

Populasi sapi potong di Sulawesi Tenggara masih mencapai 229.330 ekor (BPS Sultra 2013). Daging sapi hasil pemotongan yang ada di pasaran Kota Kendari biasa diperoleh dari RPH, namun sampai saat sampai saat ini kualitas daging sapi masih begitu kurang diperhatikan oleh masyarakat dan pemenuhan permintaan daging masih diutamakan dalam hal kuantitas saja. Hal ini dapat dilihat dari sistem pemotongan dan penanganan daging yang belum memperhatikan prinsip-prinsip teknis yang seharusnya. Padahal mutu atau kualitas karkas dan daging sapi merupakan masalah yang kompleks.

Sapi lokal yang biasa di jadikan sumber daging salah satunya adalah sapi Bali. Sapi Bali merupakan sapi pedaging yang unggul ,daging sapi Bali memiliki daging yang berkualitas karena sapi Bali merupakan ternak yang potensi genetiknya sangat baik, daya adaptasi yang tinggi dan tahan terhadap iklim buruk.

Performa seekor ternak merupakan hasil dari pengaruh faktor genetik dan faktor lingkungan. Seekor sapi yang memiliki genetik tinggi tidak akan menunjukkan performa produksi yang baik apabila tidak didukung oleh lingkungan yang baik, begitu juga sebaliknya. Otot yang berasal dari sapi yang sehat, diberi ransum dengan baik dan mendapat istirahat cukup mempunyai kadar glikogen otot yang cukup (kira-kira 1\% dari berat otot segar), yang akan dirubah menjadi asam laktat setelah mati/pemotongan (Saka 2011). Bobot karkas ternak sapi dipengaruhi oleh bobot hidup, bangsa, jenis kelamin, makanan dan kondisi tubuh ternak. Seekor sapi dianggap baik bila menghasilkan karkas dengan kuantitas dan kualitas yang optimal (Yosita et al. 2011).

Penilaian karkas sapi sangat penting dalam usaha jual beli sapi, karena karkas yang bagus akan memberikan keuntungan lebih besar (Herviyanto et al. 2015). Penilaian produksi biasanya didasarkan pada penilaian kualitas karkas yang dihasilkan. Salah satu parameter penilaian karkas yang umum adalah indeks perdagingan. Indeks perdagingan menentukan seberapa banyak proporsi daging terhadap panjang karkas sapi. Karkas yang memiliki panjang karkas sama dengan bobot karkas yang berbeda maka karkas yang lebih berat akan mempunyai indeks perdagingan lebih tinggi begitu juga sebaliknya.

Mengingat demikian pentingnya indeks perdagingan maka perlu untuk dilakukan suatu penelitian pada ternak sapi bali pada jenis kelamin berbeda untuk dapat menentukan indeks perdagingan sapi bali yang dipelihara secara tradisional dan dipotong di RPH Kota Kendari. Melalui penelitian ini akan dikaji tentang bobot karkas, panjang karkas serta 
indeks perdagingan pada ternak sapi Bali jantan dan betina, agar nantinya dapat memberikan informasi yang bermanfaat dalam perbaikan dan peningkatan produktivitas karkas sapi Bali.

\section{MATERI DAN METODE}

\section{Lokasi dan materi penelitian}

Penelitian bertempat di UPTD Rumah Potong Hewan (RPH) Dinas Pertanian, Perkebunan dan Hortikultura di Kelurahan Anggoeya Kecamatan Poasia Kota Kendari. Bahan yang digunakan adalah sapi Bali yang berjenis kelamin jantan dan betina dengan kisaran umur antara 2 - 3,5 tahun sebanyak 40 ekor (20 ekor jantan dan 20 ekor betina). Beberapa peralatan digunakan dalam penelitian ini adalah seperangkat alat jagal yang terdiri atas pisau, tali, batu asah, timbangan sapi, pita ukur dan timbangan gantung kapasitas $50 \mathrm{~kg}$.

\section{Prosedur penelitian}

Sebelum sapi disembelih dilaksanakan pemeriksaan kesehatan (antemortem) untuk dinyatakan layak sembelih dan dipuasakan 7-8 jam. Perkiraan umur sapi dilakukan dengan cara membuka mulutnya dengan menghitung jumlah gigi seri. Penimbangan sapi sebelum pemotongan untuk mendapatkan data bobot badan sapi sebelum dipotong dan pencatatan jenis kelamin. Penyembelihan sapi dilakukan secara tradisional dengan cara mengikat keempat kaki sapi dan membantingnya. Setelah rebah, selanjutnya disembelih. Proses penyembelihan sapi dilakukan secara halal menurut ajaran agama Islam dengan menggunakan pisau tajam memutuskan vena jugularis, arteri carotis, oesophagus dan trachea.

Selanjutnya pengulitan dilakukan dilantai, pengulitan diawali dengan irisan panjang pada kulit sepanjang garis tengah dada dan bagian perut (abdomen) kemudian irisan dilanjutkan sepanjang permukaan dalam (medial) kaki. Kulit dipisahkan mulai dari ventral (bagian bawah) ke arah punggung tubuh. Kemudian kepala, keempat kaki dan ekor di pisahkan. Proses eviserasi dilakukan setelah proses pengulitan selesai. Eviserasi dilakukan dengan menyayat dinding abdomen kearah dada, kemudian organ-organ yang ada di dalam perut dikeluarkan. Organ tersebut yaitu offal merah dan offal hijau. Offal merah terdiri atas limpa, ginjal, jantung, hati dan paru-paru, sedangkan offal hijau terdiri atas lambung dan usus. Selanjutnya dilakukan pengukuran panjang karkas. Data bobot karkas diperoleh dari hasil penimbangan bagian-bagian karkas sapi. Skema prosedur penelitian yaitu:

\section{Teknik pengumpulan data}

Penentuan Jenis Kelamin ditentukan berdasarkan jenis kelamin yaitu jantan atau betina dengan melihat jenis kelamin ternak. Pengukuran Panjang karkas jantan dan betina dilakukan dengan separuh karkas segar digantung pada lalu pengukuran dilakukan dari pihak sisi dalam karkas mulai dari tepi depan Os pubis vertikal lurus ke bawah sampai ke tepi depan dari tulang rusuk pertama. 


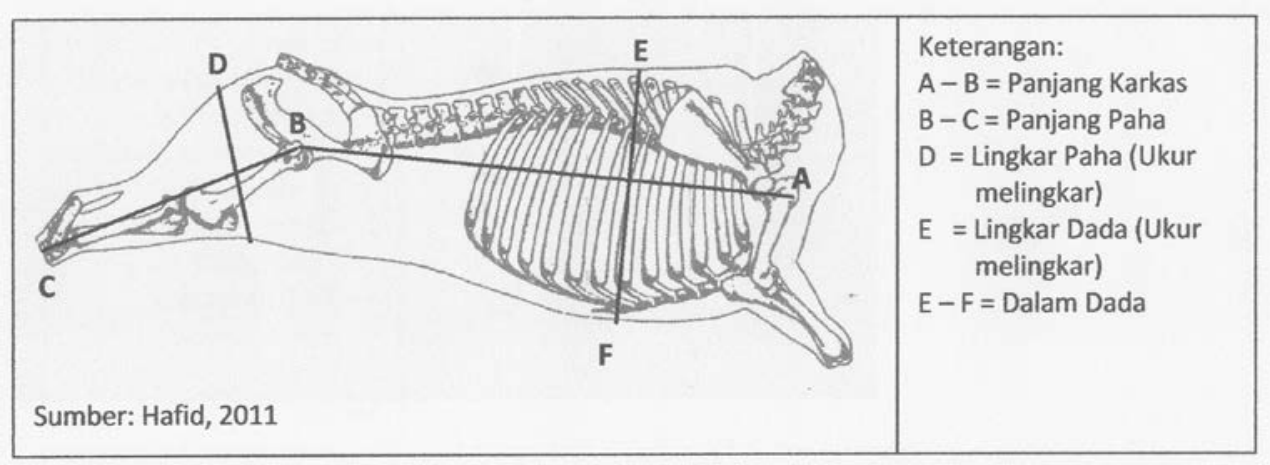

Gambar 1. Cara mengukur karkas (Hafid 2011)

\section{Variabel penelitian}

Variabel diamati dalam penelitian ini adalah penimbangan bobot karkas jantan dan betina. Penimbangan bobot karkas dilakukan setelah ternak dipotong, kemudian dipisahkan bagian-bagian karkas kemudian ditimbang menggunakan timbangan gantung kapasitas $50 \mathrm{~kg}$. Variabel lainnya adalah indeks perdagingan. Indeks perdagingan dihitung berdasarkan perbandingkan antara bobot karkas dan panjang karkas. Rumus untuk menghitung indeks perdagingan (Fleshing index) (IP) adalah sebagai berikut:

1. Penimbangan bobot karkas jantan dan betina. Penimbangan bobot karkas dilakukan setelah ternak dipotong, kemudian dipisahkan bagian-bagian karkas kemudian ditimbang menggunakan timbangan gantung kapasitas $50 \mathrm{~kg}$.

2. Indeks perdagingan. Indeks perdagingan dihitung berdasarkan perbandingkan antara bobot karkas dan panjang karkas. Rumus untuk menghitung indeks perdagingan (Fleshing index) (IP) adalah sebagai berikut (Santoso 1995):

$$
\text { Indeks Perdagingan }=\frac{\text { Bobot Karkas }}{\text { Panjang Karkas }}
$$

\section{Analisis data}

Data yang diperoleh, di tabulasi berdasarkan klasifikasi jenis kelamin selanjutnya di analisis dengan menggunakan Uji-Student sesuai dengan petunjuk (Sudjana 1996).

\section{HASIL DAN PEMBAHASAN}

Rataan bobot potong, bobot karkas, panjang karkas dan indeks perdagingan sapi Bali jantan dan betina pada pemeliharaan tradisional di Sulawesi Tenggara disajikan pada Tabel 1 berikut. 
Tabel 1. Rataan bobot potong, bobot karkas, panjang karkas dan indeks perdagingan sapi Bali jantan dan betina

\begin{tabular}{|c|c|c|c|c|c|}
\hline Jenis kelamin & Ulangan & $\begin{array}{c}\text { Bobot } \\
\text { potong } \\
(\mathrm{Kg})^{*}\end{array}$ & $\begin{array}{l}\text { Bobot } \\
\text { karkas } \\
(\mathrm{Kg})^{*}\end{array}$ & $\begin{array}{c}\text { Panjang } \\
\text { karkas }(\mathrm{cm})^{*}\end{array}$ & $\begin{array}{c}\text { Indeks } \\
\text { perdagingan } \\
(\mathrm{Kg} / \mathrm{cm})^{t n}\end{array}$ \\
\hline Jantan & 20 & $230^{\mathrm{a}}$ & $122,9^{\mathrm{a}}$ & $108,9^{\mathrm{a}}$ & 1,13 \\
\hline Betina & 20 & $212^{\mathrm{b}}$ & $114,1^{\mathrm{b}}$ & $104,7^{\mathrm{b}}$ & 1,09 \\
\hline$S_{\text {gabungan }}$ & & 6,462 & 4,880 & 2,673 & 0,441 \\
\hline
\end{tabular}

*) Berbeda nyata $\mathrm{P}<0,05) ;{ }^{t n}$ ) tidak berbeda nyata $\mathrm{P}>0,05$

\section{Bobot potong}

Secara umum bobot potong merupakan indikator penilaian dalam melakukan pengukuran pertumbuhan. Jika pengukuran dilakukan pada waktu yang teratur, maka akan diperoleh suatu kurva yang berbentuk sigmoidal (Aberle et al. 2001). Pertumbuhan menurut Hafid (2005) adalah perubahan bentuk atau ukuran seekor ternak yang dapat dinyatakan dengan panjang, volume ataupun massa. Bobot hidup akhir dipengaruhi oleh kecepatan pertumbuhan ternak tersebut, semakin ternak tersebut tumbuh maka berat hidup akan semakin besar (Nadia 2006).

Dari hasil penelitian bahwa rataan bobot potong sapi Bali jantan dan betina yang dipotong di RPH Kota Kendari yang tercantum pada Tabel 1. lebih tinggi sapi jantan daripada betina $\mathrm{P}<0,05$, dimana bobot potong sapi jantan $230 \mathrm{~kg}$ sedangkan sapi betina 212 kg. Hasil penelitian (Yosita et al. 2012) bahwa bobot badan sapi Bali yang mempunyai kondisi tubuh gemuk 344,60 kg. Sapi yang mengalami penurunan bobot badan disebabkan sebelum dilakukan pemotongan dilakukan pemuasan karena cadangan nutrisi dalam tubuhnya di pakai untuk memenuhi fungsi-fungsi fisiologis. Hal ini sejalan dengan hasil penelitian Hafid \& Rugayah (2009) bahwa terdapat kecenderungan semakin lama periode pemuasaan yang diterapkan pada seekor ternak maka risiko penurunan bobot hidup yang terjadi juga semakin besar, disebabkan oleh proses urinasi dan defekasi yang lebih banyak yang pada akhirnya berimplikasi pada bobot hidup yang semakin berkurang, dengan demikian dapat berarti bahwa penurunan bobot hidup dari seekor sapi sebesar 3,18\% masih merupakan bobot dari isi saluran pencernaan dan kantung kemih, Penurunan bobot hidup sapi Bali pada perlakuan pemuasaan ini diduga hanya disebabkan oleh penurunan bobot isi saluran pencernaan dan kantung kemih dan tidak disebabkan oleh penurunan bobot jaringan tubuh. Menurut Dewi (2004) menyebutkan bahwa pada periode istirahat yang lebih lama, bobot isi saluran pencernaan lebih rendah daripada periode istirahat yang lebih singkat. Rataan bobot badan sapi Bali yang ada di sulawesi tenggara ini masih tergolong rendah, ini di karenakan kurang tersedianya pakan yang bernutrisi tinggi sehingga bobot badan sapi tersebut tidak berkembang dari tahun ketahun.

Menurut penelitian Hafid \& Aka (2008) terjadi penyusutan bobot hidup sapi akibat adanya perbedaan jarak transportasi diduga disebabkan oleh adanya recovery energi akibat stress selama perjalanan serta penurunan bobot isi saluran pencernaan dan kantung kemih dan tidak disebabkan oleh penurunan bobot jaringan tubuh, rata-rata penyusutan yang dialami cukup besar yakni berkisar 2,14-2,48\%. Hal ini sejalan dengan penelitian Aberle et al. (2001) bahwa pengangkutan atau transportasi ternak sebelum pemotongan akan menimbulkan cekaman (stres) bahkan kelelahan sebagai akibat adanya lingkungan 
yang tidak sesuai dengan proses fisiologisnya selama perjalanan. Ternak yang di sembelih dalam keadaan darurat, karena luka atau kecapaian, mengakibatkan penegeluaran darah yang sangat sering tidak sempurna (Abustam 2012). Jika sapi yang dipotong dalam keadaan stress kualitas karkas yang dihasilkan akan menurun.

\section{Bobot karkas}

Rochman (2008) mengemukakan bahwa bobot karkas adalah bobot hidup setelah dikurangi bobot saluran pencernaan, darah, kepala, kulit dan keempat kaki mulai dari persendihan carpus atau tarsus kebawah. Seekor ternak sapi akan dianggap baik kualitasnya apabila dapat menghasilkan karkas sebesar 59\% dari bobot tubuh sapi tersebut. Sapi dengan bobot potong yang tinggi berpengaruh terhadap bobot karkas, semakin tinggi bobot potong semakin tinggi juga bobot karkas yang dihasilkan (Pradana et al. 2014).

Sesuai hasil analisis statistik seperti yang ditunjukan pada Tabel 3 menunjukan bahwa bobot karkas sapi Bali jantan sebesar 122,9 kg dan betina 114,1 kg lebih tinggi dibandingkan sapi betina berbeda nyata $\mathrm{P}<0,05$. Bobot karkas dipengaruhi dari komposisi karkas (daging, tulang dan lemak). Karakteristik komposisi karkas yang dihasilkan akan mempengaruhi nilai karkas. Karkas yang baik adalah karkas yang memiliki bobot daging tinggi, bobot tulang rendah dan lemak yang optimum (Kuswati et al. 2014). Hal ini sesuai dengan Berg \& Butterfield (1976) dan hasil penelitan Hafid (1998; 2005) yang menyatakan bahwa perbedaan steroid kelamin diantara ternak jantan dan betina mempengaruhi komposisi karkas ternak. Menurut Hafid (2005) proporsi bagian bagian karkas ini dipengaruhi oleh jaringan tulang, daging dan lemak. Hasil penelitian ini didukung dengan penelitian Saka (2011) bahwa karkas sapi-sapi jantan lebih berat daripada sapi-sapi betina. Adanya hormon testosteron atau androgen yang memberi pengaruh meningkatnya retensi nitrogen atau sintesis protein atau otot di dalam tubuh sehingga memacu laju pertumbuhan sapi-sapi jantan menjadi lebih tinggi daripada sapisapi betina. Karena itu maka pada umur fisiologi atau kronologi yang sama maka berat badan dan berat karkas sapi-sapi jantan selalu lebih tinggi daripada sapi-sapi betina (Bogs \& Merkel 1979; Saka 2011). Hafid (2005) menyatakan bahwa pertumbuhan dimana secara umum pertumbuhan otot pada ternak sapi terdiri dari: Pertumbuhan centripetal, yakni pertumbuhan dimulai dari kaki kearah badan; Pertumbuhan antero posterior, yakni pertumbuhan dari depan ke belakang atau dari otak dan kepala kebelakang kearah punggung dan ekor.

Soeharsono (2001) mengatakan bahwa fungsi fisiologis hormon kelamin ialah mempengaruhi metabolisme yang berkaitan dengan pertumbuhan melalui stimulasi sintesis protein, meningkatkan transpor asam amino ke dalam sel, mempengaruhi metabolisme karbohidrat, meningkatkan glukogenesis dalam hati, merangsang mobilisasi lemak tubuh, mempengaruhi metabolisme mineral dan memacu pertumbuhan tulang rawan, yang pada gilirannya memacu pertumbuhan. Selain itu pertumbuhan urat daging ternak jantan cenderung lebih besar daripada pertumbuhan urat daging ternak betina (Soeparno 2009).

Menurut pernyataan Wiyatna (2007) bahwa bobot karkas ternak sapi bervariasi dipengaruhi oleh bobot hidup, bangsa, jenis kelamin, makanan dan kondisi tubuh ternak. Dengan demikian semakin tinggi nilai genetik ternak kemudian diberikan tatalaksana yang baik, maka akan dihasilkan bobot karkas dan perdagingan yang baik. Dari keseluruhan berat karkas dari seekor ternak akan diperoleh rata-rata 75\% daging dan 25\% tulang, hal ini dapat dijelaskan bahwa saat pertumbuhan, tulang berkembang relatif lebih 
cepat tetapi lajunya lambat, sedangkan daging pertumbuhannya relatif lebih cepat. Pada saat pertumbuhan daging masih meningkat, pertumbuhan tulang sudah mulai konstan sehingga pertumbuhan daging dan tulang tidak seimbang (Wiyatna 2007). Hal ini sesuai dengan diungkapkan oleh Hafid (1998) bahwa setelah otot mengalami pertumbuhan maksimal, maka pertambahan bobot otot terjadi terutama karena deposisi lemak intermuskuler.

\section{Panjang karkas}

Pengukuran panjang adalah hasil pengukuran panjang pada karkas sapi setelah pemotongan diukur dari ujung depan bahu sampai ujung akhir tulang pinggul (os pubis) (Hafid 2011). Dari hasil penelitian yang tercantum pada tabel 3, bahwa panjang karkas sapi Bali jantan sebesar 108,9 (cm) dan sapi Bali betina 104,7 (cm) sesuai uji statistik panjang karkas sapi jantan dan betina menunjukan berbeda nyata $\mathrm{P}<0,05$. Sesuai hasil perlakuan menunjukan bahwa lebih panjang karkas jantan dibanding betina hal ini karena dipengaruhi hormon.

Hasil penelitian Wiyatna (2007) bahwa peningkatan panjang karkas tidak selalu diikuti dengan peningkatan bobot karkas. Secara berturut-turut sapi Madura, Bali, PO dan ACC dengan panjang karkas 145,86 cm, 148,20 cm, 149,12 cm dan 135,80 cm memiliki bobot karkas masing-masing 138,26 kg, 182,68 kg, 180,76 kg dan 192,56 kg. Menurut Yosita et al. (2011) kastrasi berpengaruh terhadap panjang karkas. Hal ini sesuai dengan pernyataan Soeparno (2005) bahwa sapi jantan yang tidak dikastrasi, karkasnya lebih panjang dibandingkan dengan sapi yang tidak dikastrasi.

\section{Indeks perdagingan}

Indeks perdagingan (fleshing index) merupakan perbandingan bobot karkas dengan panjang karkas, nilainya akan meningkat seiring dengan meningkatnya bobot potong. Karkas yang memiliki panjang karkas sama dengan bobot karkas yang berbeda maka karkas yang lebih berat akan mempunyai indeks perdagingan lebih tinggi begitu juga sebaliknya. Indeks perdagingan menentukan seberapa banyak proporsi daging terhadap panjang karkas sapi (Suryadi 2006).

Berdasarkan hasil analisis statistik pada Tabel 3 memperlihatkan bahwa indeks perdagingan sapi Bali jantan sebesar 1,13 sedangkan indeks perdagingan sapi Bali betina sebesar 1,09 tidak menunjukan perbedaan yang nyata $\mathrm{P}>0,05$. Dengan kata lain, secara statistik indeks perdagingan sapi Bali Jantan dan betina keduanya realtif sama. Namun demikian nilai indeks perdagingan ini telah memberikan gambaran tentang jumlah daging (otot dan lemak) yang di kandung pada sebuah karkas.

Menurut Penelitian Suryadi (2006) peningkatan indeks perdagingan seiring dengan meningkatnya bobot potong. Hasil penelitian Saka et al. (2011) bahwa indeks perdagingan sapi Bali jantan sebesar 1,44 dan sapi Bali betina 1,25. Yosita et al. 2011 menyatakan bahwa indeks perdagingan sapi Bali yang mempunyai kondisi tubuh gemuk sebesar 1,47, panjang karkas yang lebih pendek dengan bobot karkas yang tinggi maka akan mempunyai indeks perdagingan lebih tinggi. Sebaliknya, pada bobot karkas yang rendah sedangkan karkasnya lebih panjang, maka akan mempunyai indeks perdagingan yang lebih rendah. Perlu diketahui indeks perdagingan sapi Bali ini dari hasil penelitian menunjukan lebih tinggi indeks perdagingan sapi jantan lebih dari pada sapi Bali betina. 


\section{KESIMPULAN}

Berdasarkan hasil pembahasan maka dapat disimpulkan bahwa tidak ada perbedaan nyata antara indeks perdagingan sapi Bali jantan $(1,13)$ dengan sapi Bali betina 1,09. Namun bobot potong, bobot karkas dan panjang karkas sapi Bali jantan nyata lebih besar daripada betina.

\section{DAFTAR PUSTAKA}

Aberle ED, Forrest JC, Gerard DE, Mils EW. 2001. Principles of meat science. 4th ed. San Fransisco (USA): WH Freeman and Company.

Abustam E. 2012. Ilmu daging. Makassar (Indonesia): Masagena Press.

BPS Sultra. 2013. populasi ternak yang dipelihara oleh rumah tangga usaha peternakan sesuai jenis ternak yang diusahakan menurut wilayah dan jenis ternak. Kendari (Indonesia): Badan Pusat Statistik Sulawesi Tenggara.

Badan Pusat Statistik. 2015. Konsumsi daging dalam negeri. Jakarta (Indonesia): Badan Pusat Statistik.

Dewi SHC. 2004. Pengaruh pemberian gula, insulin dan lama istirahat sebelum pemotongan pada domba setelah pengangkutan terhadap fasilitas daging [Disertasi]. [Bogor (Indonesia)]: Institut Pertanian Bogor.

Handiwirawan E, Setiawan ED, Mathius IW, Santoso, Sudibyo A. 1998. Ukuran tubuh anak sapi Bali dan persilangannya di Nusa Tenggara Barat. Prosiding Seminar Nasional Peternakan dan Veteriner. Bogor (Indonesia): Pusat Penelitian dan Pengembangan Peternakan.

Hafid H, Nuraini, Herman. 2013. Karakteristik karkas dan bagian-bagian karkas sapi peranakan ongole jantan dan betina pada peternakan rakyat di Provinsi Sulawesi Tenggara. Prosiding Seminar Nasional Teknologi Peternakan dan Veteriner. Kendari (Indonesia): Universitas Halu Oleo.

Hafid H. 2011. Pengantar evaluasi karkas. Kendari (Indonesia): Penerbit Unhalu Press.

Hafid H, Rugayah N. 2009. Persentase karkas sapi bali pada berbagai berat badan dan lama pemuasaan sebelum pemotongan. Proseding Seminar Nasional Teknologi Peternakan dan Veteriner. Bogor (Indonesia): Pusat Penelitian dan Pengembangan Peternakan.

Hafid H, Aka R. 2008. Pengaruh jarak transportasi sebelum pemotongan terhadap karakteristik karkas sapi bali. J Agriplus. 18.

Hafid H. 1998. Kinerja produksi sapi australian comersial cross yang dipelihara secara feedlot dengan kondisi bakalan dan lama penggemukan berbeda [Tesis]. [Bogor (Indonesia)]: Institut Pertanian Bogor.

Hafid H. 2005. Kajian pertumbuhan dan distribusi daging serta estimasi produktivitas karkas sapi hasil penggemukan [Disertasi]. [Bogor (Indonesia)]: Institut Pertanian Bogor.

Herviyanto D, Kuswati H, Nugroho, Susilawati T. 2015. Bobot dan panjang karkas sapi brahman cross steer pada butt shape berbeda. Malang (Indonesia): Universitas Brawijaya.

Kuswati, Kusmartono, Susilawati T, Rosyidi D, Agus A. 2014. Carcass characteristics of brahman crossbreed cattle in Indonesian feedlot. IOSR J Agric Vet Sci. 7:19-24. 
Nadia. 2006. Persentase karkas dan komposisi kimia daging marmot lokal jantan pada berbagai level pemberian vitamin C [Skripsi]. [Bogor (Indonesia)]: Institut Pertanian Bogor.

Pradana W, Rudyanto MD, Suada IK. 2014. Hubungan umur, bobot dan karkas sapi bali betina yang dipotong di rumah potong hewan Temesi. Indones Medic Veterin. 3:37-42.

Santosa U. 1995. Tatalaksana pemeliharaan ternak sapi. Cetakan I. Jakarta (Indonesia): Penerbit Penebar Swadaya.

Saka IK, Mantra IB, Tirta Ariana IN, Oka AA, Sriyani NLP, Putra S. 2011. Karakteristik karkas sapi Bali betina dan jantan yang dipotong di rumah potong umum pesanggaran, Denpasar. Laporan Penelitian. Denpasar (Indonesia): Fakultas Peternakan, Universitas Udayana.

Soeparno. 2009. Ilmu dan teknologi daging. Yogyakarta (Indonesia): Gadjah Mada University Press.

Soeharsono. 2001. Kontroversi penggunaan hormon sebagai pemacu pertumbuhan pada produksi ternak. Bandung (Indonesia): Universitas Padjajaran.

Sudjana. 1996. Metoda statistika. Edisi Keenam. Bandung (Indonesia): Tarsito.

Suryadi U. 2006. Pengaruh bobot potong terhadap kualitas dan hasil karkas sapi Brahman Cross. J Pengembangan Peternakan Tropis. 31:21-27.

Wiyatna MF. 2007. Perbandingan indek perdagingan sapi-sapi Indonesia (Sapi Bali, Madura, PO) dengan Sapi Australian Commercial Cross (ACC). J Ilmu Ternak. 7:22-25.

Yosita M, Santosa U, Setyowati EY. 2012. Persentase karkas, tebal lemak punggung dan indeks perdagingan sapi Bali, peranakan ongole dan australian commercial cross. Sumedang (Indonesia): Fakultas Peternakan, Universitas Padjadjaran. 